\title{
Dialektisk atferdsterapi
}

Ved Ingebjørg H estetun

Senter for forebygging av selumord i Nord-Norge arrangerte et todagers innføringsseminar i dialektisk atferdsterapi (DBT) i Tromsø 13. og 14. oktober 2004. Foreleser var Kicki Kyhle, psykolog og psykoterapeut med ansvar for DBT innen voksenpsykiatri i Dalarna i Sverige. Interessen for seminaret var stor. Flesteparten av de 75 deltakerne var behandlere innen psykisk helsevern, og de kom fra hele landet.

Kicki Kyhle ga en gjennomgang av teoriene bak DBT og refererte til forskningsresultater som viser at denne type terapi er effektiv. Hun viste også hvorledesDBT anvendesi en praktisk klinisk hverdag og ledet seminardel takerne gjennom flere praktiske øvelser.

Dialektisk atferdsterapi er en behandlingsform som er utviklet spesielt for mennesker med borderline personlighetsforstyrrelse og som sliter med repeterende selvskading og selvmordsatferd. Tradisjonelle behandlingsmetoder er ofte utilstrekkelige for å hjelpe denne gruppa. DBT bygger på kognitiv teori og atferdsterapi, med innslag av dialektisk tenkning og Zen-buddisme. Den er utviklet av M arsha M . Linehan, psykolog og professor ved $U$ niversity of W ashington i Seattle, U SA . A lec M iller i N ew York har tilpasset DBT til ungdom, og en artikkel om dette er tidligere publisert i Suicidologi (M iller \& H artstein, 2002).

I følge teorien bak DBT er selvskadingen uttrykk for vansker med emosjonell regulering, der selvskading ses som en uhensiktsmessig reaksjon på overveldende og intenst smertefulle følelser. I behandlingsopplegget lærer pasientene å få kontakt med sine egne følelser og å

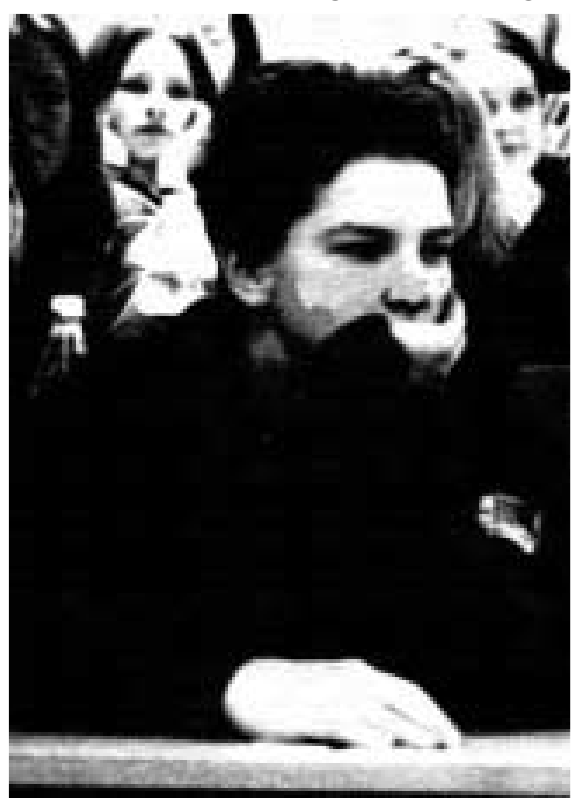

håndtere disse. Det arbeides også med utvikling av kompetanse når det gjelder å forholde seg til andre mennesker. Disse ferdighetene arbeider en med i grupper. Parallelt med dette har pasientene et individualterapeutisk tilbud.

Som regel har disse pasientene svært omfattende problemer. Den primære målsettingen med behandlingen er derfor ikke à "helbrede", men at pasienten skal bli i stand til å bruke de nye ferdighetene i krisesituasjoner i stedet for å skade seg selv eller prøve å ta sitt liv. Den overgripende målsettingen med behandlingen kan formuleres slik: "Å få et liv verdt å leve".

Det gis i dag behandlingstilbud med utgangspunkt i DBT til voksne i Fauske/ Bodø og Tromsø, og til ungdom i Skien. Deltakere fra disse stedene informerte om sin virksomhet og erfaringer. Forutsetningene for å starte opp et tilbud med dialektisk atferdsterapi er at man er minst to behandlere, helst tre. Behandlerne må gis mulighet til å få opplæring i dialektisk atferdsterapi. Fordi det er krevende å gi behandlingstilbud til pasienter med kronisk suicidalitet og selvskading, er det også avgjørende at behandlingsteamet opplever støtte fra overordnete i systemet. Behovet for et slikt behandlingstilbud er så absolutt til stede, og interessen blant fagfolk er stor.

U middelbar positiv tilbakemelding til forel eser og arrangør gir grunn til å tro at seminaret var vellykket. Det eneste som er å beklage er at mange ikke fikk mulighet til å delta på grunn av plassbegrensning.

\section{Litteraturtips:}

Kåver, A . \& N ilsonne, A . (2002). D ialektisk beteendeterapi vid emotionellt instabil personlighetsstörning. Stockholm: $\mathrm{N}$ atur och kultur.

Linehan, M .M . (2000). D ialektisk beteendeterapi: färdighetsträningsmanual. Stockholm: N atur och kultur.

Linehan, M .M . (1993).C ognitive-behavior treatment of borderline personality disorder. $\mathrm{N}$ ew York: The G uilford Press.

M iller, A . \& H artstein, J. (2002). Fremskritt i dialektisk atferdsterapi for suicidal ungdom. Suicidologi 7(3): 7-10.

http://www.med.uio.no/ipsy/ssff/tids0203/M iller.pdf

\section{Innføringskurs i Dialektisk atferdsterapi (DBT)} 6.-7. april 2005

Follo DPS i Ski vil i samarbeid med Seksjon for selvmordsforskning og -forebygging ved Universitetet i Oslo arrangere det første innføringskurset i SørNorge om denne terapiformen.

\section{Kursleder: Leg.psykolog/terapeut} K icki K yhle fra Sverige

Dialektisk atferdsterapi er utviklet av $M$ arsha Linehan i Seattle, og brukes i stadig større grad $\mathrm{i}$ arbeid med emosjonelt ustabile og selvskaden de klienter. Det blir også noen innlegg om praktisk bruk av DBT i N orge.

$M$ aks. 80 deltakere.

Påmelding innen 15. februar til: postmottak@folloklinikken.no

Pris: kr 1700,- for 2 dager, og lunsj ca 235,- pr dag

\section{Sted: Ski kinosenter / \\ $\mathbf{R}$ ainbow hotell Ski}

$O$ vernatting: Rainbow hotell Ski, kr 820,- pr natt/enkeltrom

\section{Kontaktperson:}

Sekretær Tone H aug,

G ruppeterapienheten,

Follo DPS, tlf. 64852150

Pryor, K. (1999). Don't shoot the dog.

$\mathrm{N}$ ew York : Bantam Books, 1999. Svensk utgave. (2003). Skjut inte hunden! . en bok om operant inlärning i vardagen ; översättning av Kina $M$ olitor. Ö rebro: $H$ undens förlag.

W adström, 0 . (2004). A tt förstå och påverka beteendeproblem. 3. rev. uppl. Stockholm: $\mathrm{N}$ atur och kultur.

Kåver, A . (2004). A tt leva ett liv, inte vinna ett krig: om acceptans. Stockholm: $N$ atur och kultur. $\mathrm{N}$ ilsonne, $\AA$. ( 2004. Vem är det som bestemmer i ditt liv?: om medveten närvaro. Stockholm: $\mathrm{N}$ atur och kultur. 